\title{
LINGUISTIC ANALYSIS OF ENGLISH PHOTOGRAPHY TERMINOLOGY
}

\author{
Inga Stoianova*, ORCHID ID: 0000-0003-2413-3468 \\ Free International University of Moldova, 52 Vlaicu Pârcălab str., Chișinău, Republic of Moldova \\ *Corresponding: Inga Stoianova, agnissto@mail.ru
}

Received: 11.16 .2021

Accepted: 01.15 .2022

\begin{abstract}
The purpose of the present investigation is to perform a linguistic analysis of the English vocabulary of photography as a means of professional communication. The research includes a brief historical introduction to the progress of photography (diachronic approach) to study the (co)relationship between the development of photographic science and enrichment of its specialized lexical fund based on newly formed scientific concepts. The concept and quantitative analysis of the studied corpus established the predominance of the terminological units that are part of the conceptual groups, denoting the photo camera and its settings, photo editing and printing, lighting, photography metering, and issues. The ways of formation of English terminology of photography were investigated using structural, morphological, and componential analyses. The data acquired showed a variable number of terminological units formed according to various structural models. In the process of photographic terminology formation, substantive type of terminological combinations predominates, followed by the derivative units, simple and compound terminological units. Photography abbreviations as a form of language, time, and space economy were also structurally and semantically studied.
\end{abstract}

Keywords: photographic art, term, diachronic approach, conceptual classification, structural analysis, means of formation, terminological combinations of terms, simple terms, derivatives, compounds, abbreviations.

Rezumat. Scopul prezentei investigații este de a efectua o analiză lingvistică a vocabularului în limba engleză ce ține de domeniul fotografic ca mijloc de comunicare profesională. Cercetarea include o scurtă introducere istorică în domeniul fotografiei (abordare diacronică) în vederea studierii (co)relației dintre dezvoltarea științei fotografice și îmbogățirea fondului său lexical specializat în baza conceptelor specializate nou formate. Analiza conceptuală și cantitativă a corpusului studiat a demonstrat predominarea unităților terminologice ce fac parte din grupurile conceptuale, cum ar fi: „,camera foto și setările acesteia”, ,, foto editare și printare”, „luminozitate”, „foto contorizare”, precum și „dificultăți fotografice”. Analiza structurală, morfologică și componențială a corpusului terminologic studiat a condus la determinarea modalităților de formare a terminologiei engleze din domeniul vizat. Datele obținute au demonstrat un număr variabil de unități terminologice ce sunt formate conform diferitor modele structurale. În procesul de creare a terminologiei vizate predomină îmbinările terminologice de tip substantival, urmate de unitățile derivate, termenii simpli și unitățile terminologice compuse. De asemenea, au fost supuse studiului structural-semantic abrevierile foto drept mijloc de economie lingvistică, temporală și spațială. 
Cuvinte cheie: arta fotografică, termen, abordarea diacronică, clasificarea conceptuală, analiza structurală, mijloace de formare, îmbinări terminologice, termeni simpli, derivați, compuși, abrevieri.

\section{Introduction and description of the field under investigation}

It is difficult to imagine the life of a modern person without photography. Photography as a visual information language reliably serves humanity. It has taken a firm place on the pages of newspapers and magazines, books and stands, Internet resources, and has become an independent method of research introduced into practically all spheres of human activity. With the development of digital technologies, photography is available to almost everyone. People always wanted to capture the beautiful moments of their lives, the phenomena of nature, and to express a sense of beauty through a material form. Currently millions day-today share their private, original, sentimental interpretation of the world to an extensive public, including family members, friends and foreigners. Social networks (Instagram, Facebook, Flickr, VKontacte, etc), numerous blogs, and sites invite others into their private lives. Almost 350 million photos are uploaded to Facebook daily, the total number being more than 250 billion photos [1]. As the prominent Canadian photographer and artist, James Wilson (who has been working in photography for more than 40 years) mentioned, "In the world of photography, you get to share a captured moment with other people" [2]. Thus, photography has an irreplaceable position in today's society. To understand the process of photography vocabulary contents and formation, it is proper to investigate the definition of the term and to perform a virtual trip to the history of this fascinating art. However, it would be more accurate to talk not about the history of photography, but about the technical evolution of photographic images, which at the very beginning were not considered as pieces of art [3].

Photography belongs to the group of fine arts, i.e. those perceived visually; painting, sculpture, cinema are associated with the same group of arts called plastic or elegant ones as they can be viewed and touched, existing in material expression (in space and time). The word photography means "drawing with light." The British scientist Sir John Herschel supposedly first coined it in 1839 from the Greek words phos (genitive: phōtós) meaning "light", and graphê meaning "drawing or writing”, i.e. light writing [4].

\section{Diachronic Approach to Photography Development}

The advent of photography, as a technique, is closely linked to various technological discoveries. However, the emergence of modern photo camera predecessor (proto photo camera) is much discussable. According to some sources, the history of photography began about 1000 years ago when the Arab mathematician and scientist Alhazen (Ibn al-Haytham) from Basra, interested in the behavior of light, noted the effect created by a pinhole camera: in a partially lit room, an inverted image of external objects is obtained. In his "Book of Optics", written in Cairo between 1012 and 1021, Ibn al-Haytham used the term Al-Bayt al-Muthlim, translated into English"a dark room" [5].

Others consider it was the Chinese philosopher Mo Di/Zi (ca. 470-391 BCE), who discovered and developed the fundamentals of optics and mentions the principle of camera obscura operation, later independently described by Aristotle and Euclid. The term camera obscura originates in Latin meaning "a dark room." The first description of the darkroom belongs to Leonardo da Vinci (1504), representing a box with a hole in it that allows light to pass through and create an image on the piece of paper [6]. 
In 1604, German astronomer Johannes Kepler discovered the mathematical laws of light reflection in mirrors. These laws later laid the foundation for the theory of lenses, following which the Italian physicist Galileo Galilei invented the first telescope for observing celestial bodies. The principle of rays' refraction was established.

In 1822, French scientist Joseph Nicéphore Niépce received the first image, the prototype of modern photography. The first photo is considered "View from the window at le Gras", a heliographic image and the oldest surviving camera photograph (1826). Using asphalt varnish, the image took shape and became visible. Thus, for the first time in the history of photography, a picture was created not by an artist, but by incident rays of light in refraction [7].

William Talbot's first experiments, beginning in the spring of 1834, involved coating common writing paper with silver nitrate both alone and in combination with sodium chloride. He produced his first "photogenic drawings" in 1834 and the following year made his first camera negative. On January 31, 1839, Talbot's paper "On the Art of Photogenic Drawing" was read to the Royal Society in London. When Daguerre's process was disclosed in August of 1839, it revealed that there was no overlap between the two processes [8, p. 1377].

January 7,1839 , is considered the beginning of the photography era when the French Academy of Sciences announced the invention of a completely new kind of art, or rather the technique of image production in the form of a dubbed daguerreotype. The French scientist Louis Jacques Mandé Daguerre discovered a method for obtaining a fairly high-quality image on a copper plate coated with silver and named it daguerreotype. Thus, photography came to the world thanks to the happy meeting of optics (a pinhole camera) and chemistry (photosensitive substances contribute to image creation). In the first cameras, silver and its compounds were used as a photosensitive substance [3].

In 1861, British photographer Thomas Sutton invented the first single-lens reflex camera. Three photographic plates of a tartan ribbon, taken in 1861 by Thomas Sutton through red, green, and blue filters, were used by James Clerk Maxwell to demonstrate that photography in colour could be a practical proposition [8, p. 906]. From that moment on, the development of photography as a form of art. Consequently, the history of photography is the history of the field's technology and that was just the beginning.

Dictionaries tell us that photography is "the act, process, or job of taking photographs or filming something" [9]. While the definition provides a general framework for photography, it does little to distinguish photography from other forms of visual communication. Photography pursuit is just an interest in the everyday life of a person, a concern to the communicative features of photography and in its social nature, the latter expressed in its functioning. Photography performs the functions of social control, social integration, socialization, manipulation of mass consciousness; it acts as a means of forming social identity and has innovative characteristics. Photography is not only a reflection of reality but also its creation [10, p. 51]. Here is appropriate to remind the words of one of the great photographic innovators of the last century Duane Michals asserting that "photography deals exquisitely with appearances, but nothing is what it appears to be" [2].

Photo communication is a complex and multifaceted phenomenon. On the one hand, there are certain subject-object relationships between the photographer and the photographed (object/ subject) in the process of the photographing act itself, being an indirect act of communication. The photographer creates a photo image based on his own beliefs, self-actualization needs, and the value system adopted in society. He acts in front of 
the lens, as he wants to be seen by the others. On the other hand, based on the social interaction of the subject and the object of photographing, a photo image is shaped which in the context of communication practices will be read by "viewing" the picture, i.e. by the "others." The "analyzed" image encounters the photograph(er) and contributes to the formation of the inner "I" through the "others", i.e. a system of social values, needs, norms [10, p. 52]. The same concept is rendered by the photographer Ansel Adams while stating that "there are always two people in every photo: the photographer and the viewer" [2]. We are interested not only in photography, the interaction of subjects and objects of photographic communication but also in its presentation as a social fact, the social meaning of photographic images arising in culture and their further impact on society.

\section{Conceptual Analysis of Photography Specialized Lexis}

The following step of our research involves linguistic analysis of the glossary consisting of 160 English photography terms selected by the method of continuous sampling from the specialized dictionaries and online sources [11, 12,13], as well as 98 abbreviated forms [14]. According to Halliday and Matthiessen, quoted by Sadia Irshad, the corpus of a language helps to theorize the language as it provides authentic, representative, and quantitative data [15, p. 76].

Specialized terminology is a key component of the general investigation and documentation process. The central concern of terminology is concept analysis, which involves the description of concepts by enumerating their characteristics, properties, and descriptions of relations held within the systems of concepts [16]. As Susan Myburgh states "a concept is a theoretical term referring to a property or construct (often a complex entity or phenomenon) which suggests the role it plays in a theory, or in relation to other concepts: it is the idea represented by a term or word, while conceptual analysis in practice concerns distinguishing terms, analyzing the understandings they refer to, and representing this" [17, p. 133]. According to the conceptual criterion, seven groups of terminological units can be determined in the framework of analyzed terminology: photo camera and its setting, photo lightening, photo-editing printing, photography equipment, photo metering, and photography problems, various notions. A detailed discussion of each conceptual group follows; sample English photography terms are given with their Romanian equivalents.

Photo Camera and its Setting. A camera is an optical instrument used to capture an image. At their most basic, cameras are sealed boxes (the camera body) with a small hole - the aperture (apertură/ diafragmă) that allows light to capture an image on a light-sensitive surface. Cameras have various mechanisms to control the light falling onto the light-sensitive surface. Lenses (lentilă/ obiectiv) focus the light incoming the camera, the size of the aperture can be widened or narrowed to let more or less light into the camera and a shutter mechanism determines the amount of time the photosensitive surface is exposed to the light. This group comprises the majority of selected terms of the glossary (66 units 41,3\%): flash (bliț), autophocus (sistem automat de focalizare), aspherical lens (lentilă asferică), bulb (buton), depth of field (adâncime de focalizare), large format cameras (camera de format mare), lens distortion (distorsiunea obiectivului), wide range lens (lentilă grand-anghiulară) etc.

Lighting. Light in photography refers to the natural or artificial position of light source concerning the subject. The position and quality of light can affect the final photo quality, from clarity to tone to emotion and so much more. By paying attention to how light 
plays off the angles and curves of the subject, and which parts of the subject are illuminated and which are in darkness, one can become a stronger photographer. The group includes 20 terms (12,5\%) of the corpus: bounce lighting (iluminare prin sărituri), ambient light (lumină ambiantă), existing light (lumină naturală), high-key lighting (iluminare în "cheie-înaltă"), side lighting (iluminare laterală) etc.

Photo-editing and Printing. Editing photographs enables the reproduction, publication, and distribution of all printed images; to be precise editing occurs by "sorting pictures." Editing is the stage when pictures are chosen as part of a specific photo project [12]. Photographic printing is the process of producing a final image on paper for viewing, using chemically sensitized paper. The group includes 27 terms (16,9\%) of the analyzed corpus, e.g.: cropping (decupare), dye print sublimation (tipărire prin sublimare a culorilor), file size (mărime fișier), gelatin silver print (imprimeu argintiu cu gelatină), photogravure (fotogravură), processing (procesare), negative (negativ), etc.

Photography Equipment. To get the image through the process of making pictures, a photographer needs certain equipment: camera, lens, scanner, printer, and so on. The analyzed group comprises 6 terms of the corpus (3,7\%) as enlarger (amplificator), reflector (reflector), unipod (monopied), tripod (trepied), lens hood (parasolar foto) etc.

Photography metering. Metering is how a camera determines what the correct shutter speed and aperture should be depending on the amount of light that goes into the camera and the ISO. Back in the old days of photography, cameras were not equipped with a light "meter" which is a sensor that measures the amount and intensity of light [12]. The group embraces 14 terms (8,8\%) of the corpus as dots per inch (puncte per inci/inch), exposure meter (exponometru), focal length (distanță focală), megapixel (megapixel), metering (contorizare), light meter (fotometru) etc.

Photography issues. There are certain photography problems and mistakes that commonly occur for new photographers as well as the more experienced, many of these faults are easily eliminated. This group is not so numerous consisting of 7 terms, making $4,3 \%$ of the analyzed corpus, e.g.: chromatic aberration (aberație cromatică), graininess (granulozitate), low resolution (rezoluție scăzută), diffusing (în difuzie), vignetting (vignetare), red eyes (ochii roșii).

Various notions. The group includes 20 terminological units $(2,5 \%)$ expressing various concepts from the field of photography art, e.g.: manual (modul "manual), time exposure (timpul de expunere), scene modes (moduri de scenă), background (fundal), ton (nuanță), tonal range (gamă tonală), watermark (filigran).

Therefore, the quantitative analysis of terminological units included in the analyzed corpus shows that the majority of terms denote the notions of the photo camera and its setting $(41,3 \%)$, followed by those expressing the notions of photo editing and printing $(16,9 \%)$, photo lightening $(12,5 \%)$, various photography terms $(12,5 \%)$, and photo metering $(8,8 \%)$; the groups of photography equipment $(3,7 \%)$ and photography problems $(4,3 \%)$ are less productive.

\section{Ways of Photography Art Vocabulary Formation}

The strategy of this investigation relies on the ideas of systemic functional grammar to examine the paradigmatic and syntagmatic relations of the terms or components making terminological units in the framework of the selected corpus. According to Irshad S., paradigmatic and syntagmatic relations define the lexicogrammatical structure of a lexeme 
(i.e. terminological unit). The lexemes/terms operate by establishing the relationship between paradigmatic lexical sets and paradigmatic grammatical systems [15, p. 77].

In linguistics, word formation refers to how new words are formed based on other words or morphemes. Word formation can denote either a state or a process, and it can be viewed either diachronically (through different periods in history) or synchronically (at a particular period in time). Most English vocabulary arises by making new lexemes out of old ones: either by adding an affix to previously existing forms, altering their word class, or combining them to produce compounds [18, p. 45].

In the present research, the photography terms are divided structurally into simple, derived, compound, and terminological combinations. The analyzed terminological corpus consists of single terms and terminological units. Quantitatively, single terms represent 70 units $(43,7 \%)$ of the whole corpus of the glossary: 68 substantival and 2 adjectival terms.

The first group to be analyzed is one of the simple terms, being represented by 14 terms (20\%): bulb (buton), contrast (contrast), flash (bliț), lens (lentilă/obiectiv), print (imprimare), slide (casetă foto), bokeh (bokeh), film ( film/ peliculă).

Derivative terms. Derivation is the process of creating a new word. The new, derived word is related to the original one; it has some new components of meaning and often belongs to a new category. One of the most common ways that English enriches its vocabulary is by affixing a derivational morpheme to a base. English is known to form new words by prefixing, and while adding a derivational prefix a new word is coined, its grammatical category often is not changed [18, p. 64]. Having analyzed the glossary from the point of view of derivation, it was found out that the derivative terms represent 43 units $(61,4 \%)$, i.e. the majority of the single terms and $26,9 \%$ of the whole corpus of the glossary, e.g.: exposure- expunere (verb expose + suffix -ure), metering - măsurare (noun meter + suffix -ing), reflector - reflector (verb reflect + suffix -or), underexposure- subexpunere ( prefix sub - + verb expose + suffix -ure), resolution - rezoluție (verb resolute + suffix -tion), shutter obturator (verb shut + suffix -er).

In English grammar, compounding is the process of combining two words (free morphemes) to create a new word (a noun, verb, or adjective). Also called "composition" it comes from the Latin "put together" [9]. Compounds are written sometimes as one word (sunglasses), from time to time as two hyphenated words (life-threatening), and occasionally as two separate words (football stadium). Though compounding is the most common type of word-formation in English, in the framework of the studied terminology it is not productive; just 13 terms are formed by composition, they represent $18,6 \%$ of the single terms and $8,1 \%$ of the whole corpus of the glossary, e.g.: background (fundal), darkroom (camera obscură), backlighting (lumină de fundal), watermark (filigran).

According to Halliday and Matthiesen, quoted by Irshad S., the word-classes can be viewed semantically and at their level where they enter paradigmatic relations about the choices and the syntagmatic relations entailing the company they keep. The paradigmatic analysis of lexical items (i.e. terms) reveals their semantic features whereas common patterns of terminological combination would be revealed through syntagmatic relation [15, p. 79].

Terminological combinations include two/three and four-member terms, being the largest group represented by 90 terms (56,3\% of all terms).

The group of two-member terms is the predominant among the syntagmatic terms ( 80 units $-88,9 \%$ of terminological combinations and $50 \%$ of all terms) and consists of units following the operational formulae: 
Noun + Noun (47 units/29,4\% of all terms): frame integration (integrarea cadrelor), file size (mărime fișier), lens shade (obiectiv de nuanțare), motor drive (antrenare mecanică), shutter speed (viteza obturatorului);

Adjective + Noun (33 units/ 20,6\% of all terms): blue hour („oră albastră”), automatic camera (camera automată), polarizing screen (film polarizant), dynamic range (interval dinamic), high contrast (contrast înalt), optical zoom (zoom optic), soft lighting (iluminare moale).

Some terminological units include in their structure a compound component as a chargedcoupled device (dispozitiv cuplat la încărcare).

The group of three-member terms is composed of 9 terms (10\% of syntagmatic terms and $5,7 \%$ of all terms) which have the most commonly met structures:

Noun+Noun+Noun (4 terms/ 2,5\% of all terms): dye sublimation print (tipărire prin sublimare a coloranților), medium format camera (camera de format mediu), gelatin silver print (imprimeu argintiu cu gelatină), etc;

- Adjective+Noun+Noun (5 terms/ 3,2\% of all terms): low contrast image (imagine moale), chromogenic color print (amprenta cromogenică), high rate scanning (scanare cu rata ridicată), soft focus lens (obiectiv foto cu rezoluție atenuantă), large format cameras (camera de format mare), etc.

The group of four-member terms comprises just one terminological unit $(0,6 \%)$ digital single-lens reflex camera (camera reflexivă digitală cu un singur obiectiv), built according to the formula Adj.+Adj.+N+N; the second component of the syntagm single-lens is a compound unit.

The results of our investigation show the prevalence of terminological combinations in the analyzed glossary making $56,3 \%$ (the majority of terms being nouns). The derived units (26, 9\%), simple terms (8,7\%), and compound (8, 1\%) terminological units follow them. Modern photography terminology embraces a much more varied number of lexical units formed according to various structural models.

On analyzing the terminological units in the field of photography, some abbreviated forms were selected. There is a compilation of 98 abbreviations making the corpus of the present research [14]. Abbreviations have been recently extremely popular in all fields of the English vocabulary formed by using just the initial or any other letter from a group of words. All types of abbreviations are present in the scientific and technical specialized languages and are applied frequently among professionals and technicians in the photography field. Structurally, selected 98 photography abbreviations are composed of 1-4 signs:

- 1 sign abbreviations have the form of shortenings (4 units/ 4,1\%): $A$ - aperture (diafragmă), $B$ bulb (buton), $M$ - manual (mod manual) etc.;

- 2 signs abbreviations (39 units/ 40,2\% of the corpus): EV - Exposure Value (valoarea expunerii), $K B$ - kilobyte (kylobite), MB- Megabyte (megabyte), OZ - optical zoom (zoom optic), TV - $\underline{\text { Time }}$ value (valoarea temporală), etc.;

- 3 signs abbreviations constitute the majority (45 units /45,9\%): OOF - Out of Focus (în afara obiectivului), FOV - Field of View (câmp de vedere), LCD - Liquid Crystal Display (ecran cu cristale lichide), CSC - ompact System amera (camera compactă), TTL - Ihrough the Lens (prin obiectiv) etc.;

- 4 signs abbreviations make 10 units (10,2\%): JPEG - Joint Photographic Experts Group, DSLR -

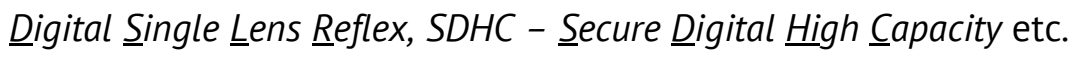

An abbreviation is defined as a shortened form of a word or phrase spelt according to the rules of a particular language. There are different types of abbreviations like clipping, blends, truncations, shortenings, acronyms, and initialisms. Although some differences when 
defining acronyms and initialisms can be determined, most authors coincide that both terms are applied to describe a lexical entity formed from one to several uppercase initial letters. However, acronyms are pronounced as one word and form a new word, while initialisms are articulated as separate sounds according to the rules of the alphabet [18, p.98]. This is the standpoint taken in the present investigation. 94 abbreviated capitalized units (four single letter shortenings are not included) are classified as:

Initialisms represent the majority of abbreviated units, making 63 units $(65,9 \%$ of the corpus): DNG [ di: əndži:] - Digital Negative Graphic, IR [ai a:] - Infrared, IQ [aikju:] - Image Quality, MS [əməs] - Memory Stick, $P Q$ [pi: kju:] - Picture Quality, SS [əsəs] - Shutter Speed, VR [vi: a:] - Vibration Reduction, PP [ pi: pi:] - Post Processing.

30 abbreviated units have the form of acronyms (30,9\%): LED [led]- Light Emitting Diode, TOG [tog] - Photographer, FOV [fov] - Field of View, BIF [bif] - Bird in Flight, EXIF [ekzif] - Exchangeable Image File Format, GIF [gif] - Graphics Interchange Format, EF [əf] Electronic Format, DOF [dof] - Depth of Field, EV [əv/ i:v] - Exposure Value, etc.

While studying the process of functioning of abbreviated forms in the language of photography art, the polysemantic nature of some abbreviated units was determined, abbreviated forms have multiple meanings in the framework of the same scientific field. For instance, the abbreviation PP in digital photography communication is applied to introduce the word Photoshop shortly. It comes out from the first and the last letters of the word - $P$ [p]. Normally the Photoshop software is in use by professional photographers, it offers many possibilities for picture optimization and getting higher images quality. Other uses for $P P$ by the photography staff are $\underline{P}$ ost- Processing, $\underline{P}$ hotographic process (the processing, developing photograph), $\underline{\text { Photo }}$ Paper, Print $\underline{\text { Processing, }}$ Photo Printer, $\underline{P}$ ocket $\underline{P}$ ouch (for digital cameras), Passport Photo and pages.

Therefore, the language of photography art is rather rich in the means of lexical units' formation including derivation, compounding, terminological combinations, and abbreviations.

\section{Conclusion}

Therefore, the technology of creating a photographic image changed our world forever becoming a truly mass phenomenon accessible to everyone. As a means of visual communication, photography performs applied, artistic, social, and communicative tasks. Photographers make expressive pictures by keeping the viewers in the mind. Selection of exposure, frame, and composition are among the means the photographers use to render an instant visual message as a piece of art.

Photography terminology develops on the ground of scientific progress and globalization. It became the instrument of professional communication and (de)codification of cultures, languages, and specialized concepts. Hence, there is a forceful trend of the denominative and conceptual terms standardization promotion. Standardization of photography terms contributes to conceptual accuracy, communicative ease, and terminological management. The language of photography embraces a structural and semantic variability of terminological and lexical units. The image-making terms of various structural types (simple, derivative, and compound terms as well as terminological combinations and abbreviations) are created to fill the denominative gap for a new concept, replace an out-of-date term of a preexisting notion, and substitute a terminological unit for a more suitable one. 


\section{References}

1. Incredible Facebook Statistics and Facts [online]. Available: https://www.brandwatch.com/blog/facebookstatistics/ Accessed 10.11.2021]

2. Photography Quotes [online]. Available: https://shotkit.com/photography-quotes [Accessed: 26.12.2021].

3. History of Photography Development. [online]. Available at: https://www.takefoto.ru/articles/raznoe/284_istoriya_razvitiya_fotografii [ Accessed 15.12.2021] [ in Russian]

4. History of Photography. [online]. Available at: http://people.sabanciuniv.edu/muratgermen/history-ofphotography/history\%20of\%20photography.pdf [Accessed 24.01.2022]

5. Alhazen Builds the First Camera Obscura [online]. Available: https://www.historyofinformation.com/detail.php?entryid=2414 [ Accessed: 20.12.2021]

6. Gombos A. Istoria fotografiei; Heliografia și dagherotipia. In: Arta și artisti vizuali, anul 1, nr. 2. [online]. Available: https://artasiartistivizuali.ro/arte-plastice/fotografie/istoria-fotografiei-heliografia-sidagherotipia/. [Accessed 20.01.2022]

7. Doble R. A Brief History of Light \& Photography. [online]. Available at: https://www.researchgate.net/publication/265612332_A_Brief_History_of_Light_Photography/link/5416c36 30cf2788c4b35e519/download [Accessed 20.01.2022]

8. Hannavy J. Encyclopedia of Nineteenth-Century Photography. London: Routledge, 2013. 1630 p.

9. Oxford Learner's Dictionary [online]. Available: https://www.oxfordlearnersdictionaries.com/ [Accessed 15.12.2021]

10. Afanasieva S. Social Nature of Photography. In: Theory and Practice of Social Development, №2, 2012, p. 50-54. [in Russian]

11. A Guide to Basic Photography Terms. [online]. Available: https://www.adobe.com/creativecloud/photography/discover/photography-terms.html [Accessed 08.11.2021]

12. George Chris. Dictionary of Photography Terms. [online]. Available: https://www.digitalcameraworld.com/features/dictionary-of-photography-terms [Accessed 15.11.2021]

13. Photography Terminology. [online]. Available: https://digital-photography-school.com/deciphering-photojargon-learn-to-speak-photographer/ [ Accessed 10.10.2021]

14. Photography Abbreviations and Meanings: A Comprehensive List. [online]. Available: https://www.naturettl.com/a-list-of-common-photography-abbreviations/ [Accessed 24.11.2021]

15. Irshad S., Arshad S., Saba K. Lexicogrammatical Features of Covid-19: A Syntagmatic and Paradigmatic Corpus Based Analysis. In: CORPORUM: Journal of Corpus Linguistics, Vol. 4 No. 2 (2021), pp. $76-94$

16. Skuce D., Meyer I. Concept Analysis And Terminology: A Knowledge-Based Approach To Documentation. [online]. Available: https://aclanthology.org/C90-1011.pdf. [Accessed 19.01.2022]

17. Myburgh S., Tammaro A. M. Exploring Education for Digital Librarians. Cambridge: Chandos Publishing, 2013. $334 \mathrm{p}$.

18. Kovalenko G. Lexicology of the English Language. Kyïv: Kyïv State University, 2011. 